EUROPEAN HONORS COUNCIL

Note

\title{
Discussion Facilitation Techniques for Honors Peer Educators
}

Amber Zoe Smith ${ }^{1}$

1. Virginia Tech Honors College, United States of America; azsmith@vt.edu

Received: 27 January 2017; Accepted: 18 April 2017; Published: 28 April 2017

Keywords: discussion-based teaching, peer education, honors

\section{Introduction}

In the Virginia Tech Honors College, honors peer educators are students who apply to be the sole instructors for discussion-based classes, such as first-year seminars and reading seminars, for academic credit (Smith, 2016). This research suggests that discussion-based teaching is an effective way of meeting honors students' needs, and it describes discussionbased teaching techniques that are accessible and beneficial to honors peer educators.

\section{Characteristics of Honors Students}

My initial research summarizes characteristics of honors students to determine what kind of personal and academic support honors seminars should provide. That information is summarized in the following diagrams (figures 1 and 2) based on the work of Cuevas (2015), Lancaster (2014), Scager et al. (2012), Shepherd \& Shepherd (2014), and Shushok (2002).

\section{Figure 1. Characteristics of Honors Students: Common Strengths}

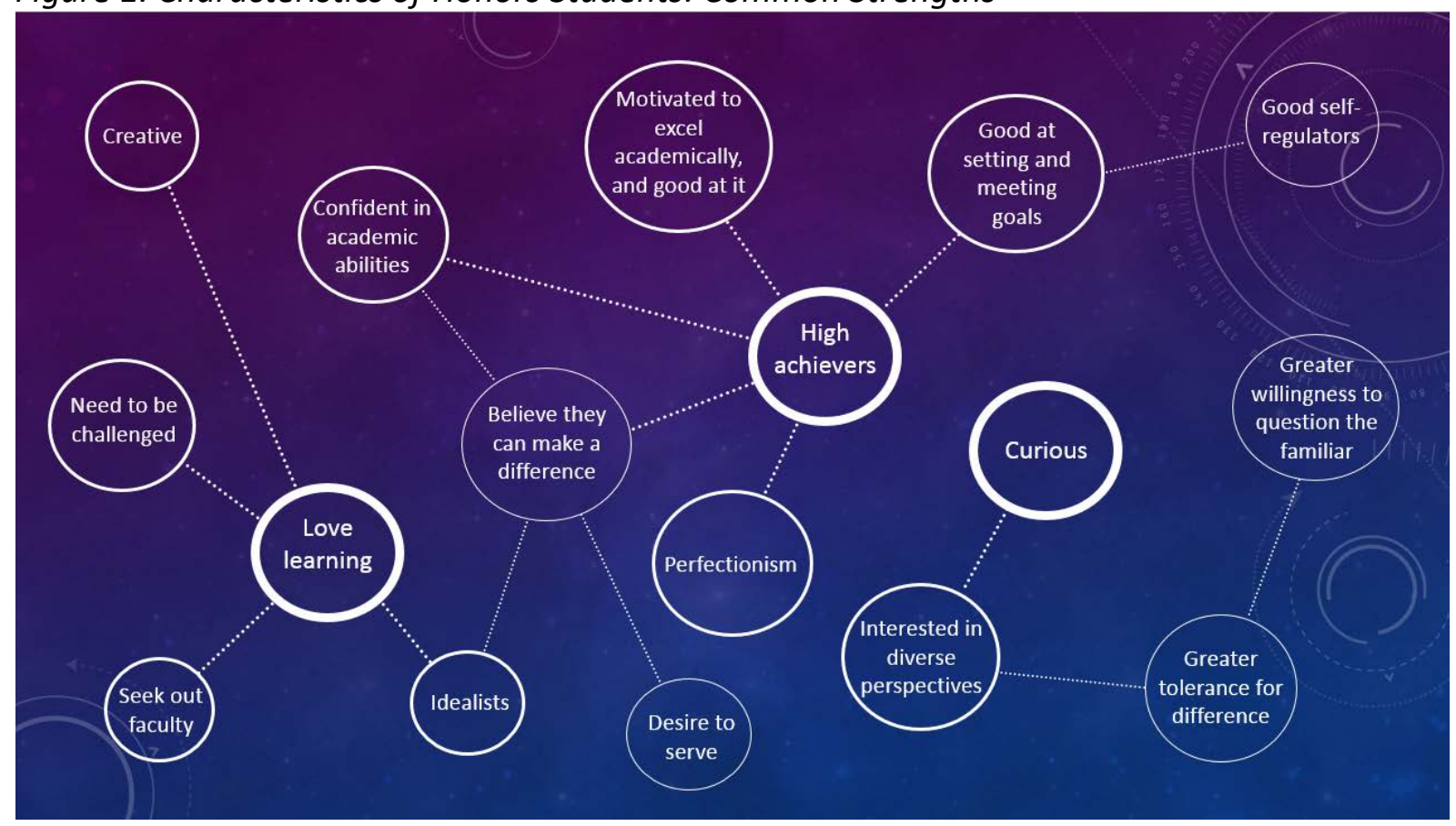


Figure 2. Characteristics of Honors Students: Common Risks

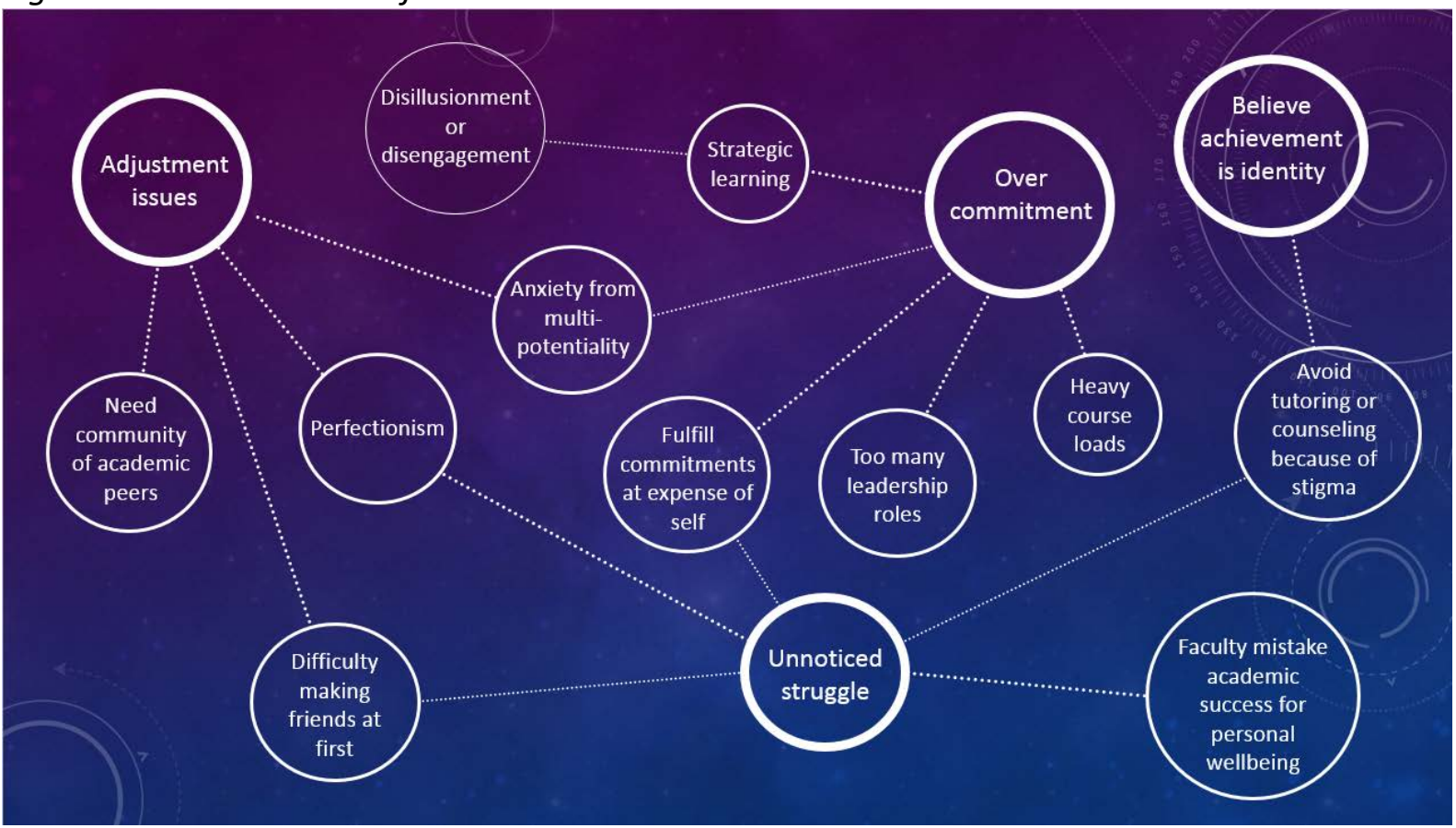

From this information, we have drawn several conclusions about the academic and personal support that honors seminars should provide. To support students academically, we can offer real challenges that result in deep learning, but we should free students to work creatively, connect them with faculty and peers, and ideally enable them to make a positive real-world impact. These practices will maximize student engagement and satisfaction. For personal support, honors seminars should strive to become communities. Classroom communities can help students adjust to college, make friends with similar academic values, and even reduce destructive behaviors, such as avoiding tutoring or counseling out of the fear that needing these services undermines their identity as high achievers. We seek to accomplish these goals in part by training our peer educators in discussion-based teaching.

\section{Discussion-Based Teaching}

Discussion-based teaching amplifies the collaborative nature of peer learning and fosters academic community by valuing all voices. Brookfield \& Preskill (2005) identify 15 benefits of discussion, many of which address honors students' needs, such as the need for diverse perspectives or a community of academic peers. Discussion also complements and enhances honors seminars that are exploratory, reflective, self-guided, and based on relationships and skills rather than disciplinary content.

However, discussion can cause harm when practiced without thorough training. Some common pitfalls include lectures disguised as discussions, domination by a few voices (often the discussion leader!), competitive quantity-over-quality participation, and reinforcement of societal injustices (Brookfield \& Preskill, 2005). For example, the latter can occur if peer educators recreate their own educational experiences without accounting for diversity, thereby promoting classroom lingo, behavioral norms, and activities that reflect mainly majority groups. Then in order for students outside of those groups to be perceived as smart or normal, they may feel pressure to suppress their cultural differences-a personally and 
academically destructive consequence (Brookfield \& Preskill, 2005). Again, thorough peer educator training can mitigate these risks so that honors students can benefit from critical, inclusive discussions.

\section{Fundamental Discussion Skills}

To facilitate effective discussions, peer educators need training in fundamental discussion skills: questioning, listening, and responding.

\section{Questioning}

Certain types of questions typically lead to stronger critical thinking, engagement, and student confidence; these types include requests for evidence or clarification, "how" or "why" questions, cause-and-effect questions, summary and synthesis questions, sincere questions, and the students' own questions (Brookfield \& Preskill, 2005; Heilker, 2007).

\section{Listening}

Strong listening skills can create a sense of continuity and community while focusing discussion on student contributions. Peer educators should listen to absorb what students share, how they share it, and how it fits into the overall discussion (Brookfield \& Preskill, 2005). They can then use this information to illuminate connections and challenge or support students as individuals.

\section{Responding}

To help students develop knowledge for themselves, peer educators should resist the urge to answer all questions; instead, they should redirect questions back to the students to encourage collaborative learning and to demonstrate that students are cocreators of knowledge (Heilker, 2007). Responding with sincere and specific praise can build student confidence while also rewarding desirable participation habits (Brookfield \& Preskill, 2005). Finally, responding with silence can help students absorb important or complicated information, take time to develop higher quality answers, or honor someone's significant or emotional contribution (Brookfield \& Preskill, 2005). To be more comfortable and effective, silence should be structured through requests such as "I'm going to ask a question, and I'd like everyone to wait a minute or two before responding so that everyone has time to develop an answer" or "Take five minutes to jot down your thoughts on this topic, and then we'll discuss it."

\section{Small Group Activities}

One of the best and most accessible ways to enhance a discussion-based class is to incorporate goal-directed small group work. These activities can help develop critical thinking skills, build confidence, form classroom communities, renew engagement, and improve subsequent full-class discussion (Bean, 2001).

The most versatile and effective activity that we use is Think-Pair-Share (Lyman, 1981). The intent of this sequence is to deeply explore a topic in a way that enables all students to participate. The "think" component is individual: students brainstorm, free write, or otherwise digest information alone. Next, they share their thoughts in pairs, each seeking to understand the other's perspective and refine their own. Finally, the pairs report the main points of their discussion to the class as a whole. 
Think-pair-share discussions are useful for challenging, complicated, or sensitive topics. Every student has to come up with an idea or argument of their own, every student gets to share it out loud but privately, and then the class benefits from a variety of perspectives that have been collaboratively refined without being as highly influenced by group think. This sequence improves student participation, enables greater depth and diversity of discussion, and helps students bond with their peers.

For more discussion-based small group activities, please refer to the work by Bean and Brookfield \& Preskill.

\section{Acknowledgements}

I would like to thank Alyssa Noble, Paul Heilker, Sara Vandyke, Paul Knox, Shelley Reid, Jason Crafton, and the Virginia Tech honors peer educators for their support of this research.

\section{References}

Bean, J. C. (2001). Engaging ideas: The professor's guide to integrating writing, critical thinking, and active learning in the classroom. San Francisco, CA: Jossey-Bass.

Brookfield, S. D. \& Preskill, S. (2005). Discussion as a way of teaching: Tools and techniques for democratic classrooms. 2nd ed. San Francisco, CA: Jossey-Bass.

Cuevas, A. E. P. (2015). Thriving in college: Predictors of honors student academic, psychological, and social well-being (Order No. 3715833). Available from ProQuest Dissertations \& Theses Global. (1708942472). Retrieved from:

http://login.ezproxy.lib.vt.edu/login?url=http://search.proquest.com.ezproxy.lib.vt.edu/doc view/1708942472?accountid $=14826$

Heilker, P. (2007). Creating active citizens: Fostering effective student writing and speaking. In E.S. Geller \& P.K. Lehman (Eds.), Teaching Excellence at a Research-Centered University: Energy, Empathy, and Engagement in the Classroom (pp. 131-138). Boston, MA: Pearson Custom Publishing.

Lancaster, D. L. (2014). Using psychosocial development theory and personality typology in identifying at-risk characteristics of college honors students (Order No. 3682287). Available from ProQuest Dissertations \& Theses Global. (1657428425). Retrieved from:

http://login.ezproxy.lib.vt.edu/login?url=http://search.proquest.com.ezproxy.lib.vt.edu/doc view/1657428425?accountid=14826

Lyman, F.T. (1981). The responsive classroom discussion: The inclusion of all students. In A.S. Anderson (Ed.), Mainstreaming Digest (pp. 109-113). College Park, MD: University of Maryland Press. Retrieved from: https://archive.org/details/mdu-univarch-027524 
Scager, K., Akkerman, S., Keesen, F., Mainhard, M., Pilot, A., \& Wubbels, T. (2012). Do honors students have more potential for excellence in their professional lives? Higher Education, 64(1), 19-39. Retrieved from:

http://www.jstor.org.ezproxy.lib.vt.edu/stable/41477917

Shepherd, G. \& Shepherd, G. (2014). Civic tolerance among honors students. Journal Of The National Collegiate Honors Council, 15(1), 85-113.

Shushok, F. X., Jr. (2002). Educating the best and the brightest: Collegiate honors programs and the intellectual, social and psychological development of students (Order No. 3070562). Available from ProQuest Dissertations \& Theses Global. (305592680). Retrieved from:

http://login.ezproxy.lib.vt.edu/login?url=http://search.proquest.com.ezproxy.lib.vt.edu/doc view/305592680?accountid $=14826$

Smith, A. Z. (2016). Supporting peer educators in first-year honors seminars at Virginia Tech. Honors in Higher Education, 1. Retrieved from: https://journals.psu.edu/heru/article/view/60067 